\title{
GENETIC DIVERSITY FOR SOME NUTRITIVE TRAITS OF CHICKPEA (Cicer arietinum L.) FROM DIFFERENT REGIONS IN KOSOVA
}

\author{
Sali ALIU ${ }^{l}$, H.-P. KAUL ${ }^{2}$, Imer RUSINOVCI I, Vitore SHALA-MAYRHOFER ${ }^{2}$, Shukri FETAHU ${ }^{l}$, \\ Dukagjin $Z E K A^{1,3}$ \\ ${ }^{1}$ University of Prishtina, Faculty of Agriculture, Department of Crop Science, Prishtina, KOSOVA \\ ${ }^{2}$ BOKU - University of Natural Resources and Life Sciences, Vienna, Department of Crop Sciences, \\ Division of Agronomy, Tulln, AUSTRIA \\ ${ }^{1.3}$ Czech University of Life Sciences Prague, Faculty of Agrobiology, Food and Natural Resources, \\ Department of Genetic and Breeding, Prague, CZECH REPUBLIC
}

Corresponding author:imer.rusinovci@uni-pr.edu

Received: 25.01 .2016

\begin{abstract}
Chickpea (Cicer arietinum L.) is an important pulse crop with a wide range of potential nutritional benefits because of its chemical composition. Seeds from seven chickpea genotypes were evaluated for their proximate analysis for quantitative traits, protein, oil and mineral composition. The experimental material comprising 7 genotypes of chickpea was grown in a Randomized Complete Block Design (RCBD) with three replications during the vegetation periods 2013 and 2014 in Ferizaj locality, in the southern part of Kosova $35 \mathrm{~km}$ away from capital city Pristina. The results showed that there was wide variation among chickpea genotypes. Grain yield was $22.72 \mathrm{~g}$ plant $^{-1}$ while protein was $28.85 \mathrm{~g} / 100 \mathrm{~g}$. Genotypes FBV-RA and FBV-FE exhibited the highest protein content $($ mean $=29.70 \mathrm{~g} / 100 \mathrm{~g}$ and $29.66 \mathrm{~g} / 100 \mathrm{~g}$, respectively). Oil content was $2.878 \mathrm{~g} / 100 \mathrm{~g}$. Also genotypic differences for mineral content were statistically significant. It was observed that the first three principal components explained $96.3 \%$ of the variability. Based on cluster analyses, the chickpea genotypes were classified into four main groups. Generally, results and findings suggest to be a great chance of genetic improvements in chickpea.
\end{abstract}

Keywords: Chickpea, Cicer arietinum, mineral content, oil, protein

\section{INTRODUCTION}

The knowledge of genetic diversity is a useful tool in gene-bank management and breeding experiments like tagging of germplasm, identification and/or elimination of duplicates in the gene stock and establishment of core collections. Chickpea (Cicer arietinum L.) belongs to the family Fabaceae. The genus Cicer L. comprises 49 taxa with 40 wild perennials, 8 wild annuals and one annual cultivated species (Toker et al. 2014; Smykal et al. 2015). Chickpea is the second most important food legume in the world in terms of area (13.5 million hectares) and production (13.1 million tons) in 2013 after beans (FAOSTAT 2016). It was domesticated in association with other crops as part of the evolution of agriculture in the Fertile Crescent 12 000-10 000 years ago (Zohary and Hopf 2000). The crop certainly originates from Turkey and Syria (Ladizinsky and Adler 1976; Toker 2009), and its progenitor ( $C$. reticulatum Ladiz.) is an endemic species to South and East Turkey (Toker et al. 2014). The major chickpea producing countries in the world are India, Australia, Turkey, Pakistan and Iran. In Europe, the crop was perhaps diffused by the Spanish and Portuguese travelers (van der Maesen 1987). Today the crop is widely distributed, being grown in over 33 countries in the world including South Asia, West Asia, North and East Africa, Southern Europe, North and South America and Australia (Anbessa et al. 2007). Chickpea is mainly produced in arid or semiarid environments. Due to several morphological and physiological advantages, the crop can effectively cope with drought conditions (Neugschwandtner et al., 2013). Chickpea yields, yield components and protein contents are affected by production system and fertilization regime (Caliskan et al. 2013). In part of the Balkan area, the crop was cultivated earlier, also in Kosovo. Here it was used after roasting for preparation of white coffee like "surogat". Seeds of chickpea were also used for food in the form of rolls. In the region of Dalmatia, this crop is still cultivated but not in large area (Gagro 1997). There it is known as "Çiçeron", which is 
probably synonymous of the Illyricum word 'qe çerohet'. Dalmatia previously has been colonized by the Illyrians. Perhaps this word is also connected with Albanian languages and today has the same sense (Aliu et al. 2010 and 2015). Although chickpea is not a common crop in Central Europe, it could provide an alternative for food and feed protein production in the face of climate change. Recently, the plant has been tested in semiarid regions of Austria (Neugschwandtner et al. 2013), the Northern Great Plains in North America (Miller et al. 2002) and in western Canada (Anbessa et al. 2007). Furthermore, the adoption of chickpea in Central Europe could lead to crop diversification and improved productivity of sustainable agricultural systems as legumes satisfy a bulk of their $\mathrm{N}$ demand from atmospheric $\mathrm{N}$ through symbiosis with $\mathrm{N}$ fixing rhizobia (Neugschwandtner et al. 2014). In agronomic practices it is used in crop rotation (Sahin and Gecit 2006) for its atmospheric nitrogen fixation ability and maintenance of soil fertility (Caliskan et al. 2013). From the nutritive values, one of the oldest groups of agricultural plants are food legumes which are the second most important human's food supply after the cereal grains. Their grain contains 38 to $59 \%$ carbohydrate, 4.8 to $5.9 \%$ oil, $3 \%$ ash, $3 \%$ fiber, $0.2 \%$ calcium, and $0.3 \%$ phosphorus (Hulse, 1991). A number of vital minerals like calcium, magnesium, zinc, potassium, iron, phosphorus and vitamins thiamine and niacine required by human body are also found in chickpea (Zia-Ul-Haq et al. 2007). Chickpea packs two to three times more protein (Tonk et al. 2010) and oil in their seeds compared to cereals (Tonk et al. 2010). This crop has been named as "poor man's meat and rich man's vegetable". Therefore, an experiment was conducted to assess genetic variation, trait association and significant contribution of each trait towards yield. Also nutritionally valuable minerals and their contribution were included to identify divergent parents for future hybridization programmes for yield and quality improvement.

\section{MATERIALS AND METHODS}

\section{Site conditions}

Kosovo has a central geographic position on the Balkan Peninsula. It lies between 41 ${ }^{\circ} 50^{\prime} 58^{\prime \prime}$ and $43^{\circ} 51^{\prime} 42^{\prime \prime}$ northern latitude and $20^{\circ} 01^{\prime} 30^{\prime \prime}$ and $21^{\circ} 48^{\prime} 02^{\prime \prime}$ eastern longitude. The experiment was carried out in Ferizaj, $21^{\circ} 06^{\prime} 25^{\prime \prime}$ Longitude, $42^{\circ} 22^{\prime} 48^{\prime \prime}$ Latitude, on altitude: $611 \mathrm{~m}$ a.s.1. in southern part of Kosovo during years 2013 and 2014. All genotypes were collected in different parts of Kosova (Table 1) from our expedition during year 2012. This region has a continental climate, rainfall averaging about $616.9 \mathrm{~mm}$ per year and mean annual temperature of about $11.9{ }^{\circ} \mathrm{C}$. Summer temperatures exceed $35{ }^{\circ} \mathrm{C}$ resulting in high evapotranspiration (HMIK, 2014). The area is characterized by flat topography. The soil is classified as of alluvial origin and rich in calcareous sediments $(\mathrm{pH}$ 7.1). The temperature was considerable higher in 2013 than in 2014. Total rainfall in 2013 was $566.5 \mathrm{~mm}$ and $743.2 \mathrm{~mm}$ in 2014. Average temperature in 2013 and 2014 was $11.9^{\circ} \mathrm{C}$ and $11.3^{\circ} \mathrm{C}$, respectively. Monthly precipitation for years 2013 and 2014 was highly above average in April (40.4 and $52.30 \mathrm{~mm}$ ) and May (122.3 and $154.2 \mathrm{~mm}$ ). Table 2 shows the long-term average monthly temperatures and precipitation an observations during years 2013-2014.

Table 1. Name and geographical origins of investigated genotypes

\begin{tabular}{llllllll}
\hline Genotype number & Genotype name & Maturity Type & Type & Longitude & Latitude & Altitude & Origin \\
\hline 1 & FBV-XE & Late (L) & Kabuli & $20^{\circ} 43^{\prime} 59^{\prime \prime}$ & $42^{\circ} 16^{\prime} 49^{\prime \prime}$ & 326 & Xerxe \\
2 & FBV-SU & Semi late (SL) & Kabuli & $20^{\circ} 46^{\prime} 08^{\prime \prime}$ & $42^{\circ} 05^{\prime} 06^{\prime \prime}$ & 356 & Suhareka \\
3 & FBV-PZ & Semi late (SL) & Kabuli & $20^{\circ} 41^{\prime} 59^{\prime \prime}$ & $42^{\circ} 14^{\prime} 15^{\prime \prime}$ & 379 & Prizren \\
4 & FBV-SU-2 & Early (E) & Kabuli & $20^{\circ} 49^{\prime} 48^{\prime \prime}$ & $42^{\circ} 20^{\prime} 25^{\prime \prime}$ & 412 & Suhareka \\
5 & FBV-FE & Late (L) & Kabuli & $21^{\circ} 13^{\prime} 32^{\prime \prime}$ & $42^{\circ} 20^{\prime} 12^{\prime \prime}$ & 562 & Ferizaj \\
6 & FBV-RA & Semi late (SL) & Kabuli & $20^{\circ} 26^{\prime} 39^{\prime \prime}$ & $42^{\circ} 45^{\prime} 54^{\prime \prime}$ & 580 & Rahovec \\
7 & FBV-MA & Semi early SE) & Kabuli & $20^{\circ} 42^{\prime} 26^{\prime \prime}$ & $42^{\circ} 36^{\prime} 46^{\prime \prime}$ & 380 & Malisheve \\
\hline
\end{tabular}

Table 2. Long term average monthly temperature and precipitation and observations during 2013-2014 growing seasons.

\begin{tabular}{lllllll}
\hline \multirow{2}{*}{ Month } & \multicolumn{3}{c}{ Precipitation $(\mathbf{m m})$} & \multicolumn{3}{c}{ Temperature $\left({ }^{\mathbf{0}} \mathbf{C}\right)$} \\
\cline { 2 - 7 } & $\mathbf{2 0 1 3}$ & $\mathbf{2 0 1 4}$ & $\mathbf{L T A}$ & $\mathbf{2 0 1 3}$ & $\mathbf{2 0 1 4}$ & LTA \\
\hline January & 38.70 & 34.50 & 36.60 & 1.60 & -0.10 & 0.75 \\
February & 5.80 & 12.50 & 9.15 & 3.90 & 2.50 & 3.20 \\
March & 70.30 & 74.50 & 72.40 & 6.60 & 6.20 & 6.40 \\
April & 40.40 & 52.30 & 46.35 & 12.80 & 11.30 & 12.05 \\
May & 122.30 & 154.20 & 138.25 & 16.70 & 15.30 & 16.00 \\
June & 55.30 & 65.50 & 60.40 & 19.00 & 20.00 & 19.50 \\
July & 32.60 & 68.90 & 50.75 & 21.60 & 21.10 & 21.35 \\
August & 21.20 & 71.50 & 46.35 & 23.40 & 22.50 & 22.95 \\
September & 56.60 & 58.50 & 57.55 & 16.80 & 15.30 & 16.05 \\
October & 64.80 & 48.70 & 56.75 & 12.60 & 12.50 & 12.55 \\
November & 42.60 & 49.80 & 46.20 & 7.40 & 7.30 & 7.35 \\
December & 15.90 & 52.30 & 34.10 & 0.70 & 2.10 & 1.40 \\
\hline Average & 566.50 & 743.20 & 54.57 & 11.90 & 11.30 & 11.63 \\
\hline *TA - Long Term Average & & & & &
\end{tabular}

*LTA - Long Term Average 


\section{Experimental design}

The experimental material comprising 7 genotypes of chickpea was grown during growing seasons of 2013 and 2014 in a Randomized Complete Block Design (RCBD) with three replications. The seeds were sown in row distance of $40 \mathrm{~cm}$. The plot sizes were $2 \times 1.5 \mathrm{~m}$. Seeds were placed at 2-3 cm depth in each row keeping $15 \mathrm{~cm}$ distance between two hills. Two seeds were sown in each hill. The excess plants were thinned out keeping one plant in each hill 15 days after sowing (DAS). The plots were fertilized with $30 \mathrm{~kg} \mathrm{ha}^{-1} \mathrm{~N}, 60 \mathrm{~kg} \mathrm{ha}^{-1} \mathrm{P}_{2} \mathrm{O}_{5}$ and $60 \mathrm{~kg} \mathrm{ha}^{-1}$ $\mathrm{K}_{2} \mathrm{O}$. The grain yields $\left(\mathrm{g}\right.$ plant $\left.^{-1}\right)$ were measured by harvesting each plot at crop maturity. Six plants were randomly chosen from each plot to measure the agronomic traits including biological shoot yield per plant (g), 100 seed weight $(\mathrm{g})$, shoot biomass without pods (g), grain yield (g), and harvest index (\%).

\section{Laboratory studies}

At harvest time, six random plants were selected in each plot and grains were carefully removed by hand. From each plant, an equal number of grains was taken from each plot, mixed together in order to form a representative sample and then subjected to proximate analyses in the laboratory. The grains were grounded to form a fine powder. The chemical analyses $(\mathrm{g} / 100 \mathrm{~g})$ included protein content (PC), cellulose content (CC), fat content (FC) and mineral content (MC). Analyses were based on standard methods: PC was determined based on Kjeldahl-N, while FC was determined by extraction using Soxhlet method (using petroleum ether at boiling point $40-60^{\circ} \mathrm{C}$ ). The cellulose was determined by the method of Updegroff (1969). Plant fiber was soaked in acetic acid and nitric acid to remove lignin, hemicelluloses and xylans. Cellulose in the sample was hydrolyzed to sugars and results are expressed as percent on dry weight basis. $\mathrm{MC}$ was determined by dry incineration at $550^{\circ} \mathrm{C}$ for $4-6$ hours. The mineral elements $\mathrm{Fe}, \mathrm{Ca}, \mathrm{Zn}, \mathrm{Mg}, \mathrm{Na}, \mathrm{Mn}, \mathrm{K}$ and $\mathrm{Cu}$ in $\left(\mathrm{mg} \mathrm{kg}^{-1}\right)$ were determined from the ash that was subsequently digested in $\mathrm{HCl}$ (ratio 1:4) and analyzed with an atomic absorption spectrophotometer (1100 B Perkin-Elmer, Germany). The carbohydrate content (on dry weight basis) was calculated by the differences:

$$
\begin{gathered}
{[100-(\mathrm{PC}+\mathrm{FC}+\mathrm{MC}+\text { crude fiber })] .} \\
\text { Statistical analysis }
\end{gathered}
$$

All statistical analyses were performed using SPSS 15.0 (SPSS, Inc., Chicago, USA). The analysis of variance and Duncan's Multiple Range Test (DMRT) were performed to test factorial effects and differences between means. Mean values of the agronomic traits for genotypes were standardized and used for computing Euclidean distances between them. Principal component analyses (PCA) and cluster analyses were used to obtain Euclidean distances between genotypes and to characterize the relation to the most discriminating traits. A $P$ value < 0.05 was considered significant.

\section{RESULTS AND DISCUSSION}

Mean squares for different agronomic traits which are included in our investigations are presented in Table 3. All sources of variance were found as statistically significant for biological yield, shoot biomass, grain yield, seed protein, oil, cellulose, carbohydrates content and harvest Index, while interaction between genotypes $(\mathrm{G})$ x year $(\mathrm{Y})$ were not statistically significantly for some traits. The variability among genotypes was high for biological yield (BY), plant biomass without pods (PB), grain yield (GY), 100 -seed weight and harvest index (HI). The average values for biological yield were $75.82 \mathrm{~g} \mathrm{plant}^{-1}$ and shoot biomass without pods $\left(53.18 \mathrm{~g} \mathrm{plant}^{-1}\right)$. The differences between them were $22.64 \mathrm{~g} \mathrm{plant}^{-1}$. Talebi et al. (2008). For plant biomass we found on average $20.1 \mathrm{~g} \mathrm{plant}^{-1}$. The chickpea genotype FBV-XE had significantly higher biological yield (118.5 $\left.\mathrm{g} \mathrm{plant}^{-1}\right)$, while FBV-SU-2 realized the lowest value for biological yield (57.65 g plant $^{-1}$ ). Thus the range was $65.85 \mathrm{~g} \mathrm{plant}^{-1}$. The final grain yield $\left(\mathrm{g} \mathrm{plant}^{-1}\right)$ in chickpea genotypes is considered to be a combined effect of various yield components, like number of seeds per plant, number of pods per plant, number of grains per pod, weight of grains per pod and 100-seed weight could be the responsible traits for yield change (Toker 2004; Toker and Cagirgan 2004). The mean value of grain yield across all genotypes was 22.72 g plant ${ }^{-1}$ and that was relatively high and may be could guarantee a high yield. Results of the grain yield exhibited significant differences among genotypes (Table 3). FBVFE had the highest grain yield $\left(30.35 \mathrm{~g} \mathrm{plant}^{-1}\right)$, while FBV-SU-2 showed the lowest grain yield (18.57 $\mathrm{g} \mathrm{plant}^{-}$ $\left.{ }^{1}\right)$. The range was $11.78 \mathrm{~g} \mathrm{plant}^{-1}(51.84 \%)$. Different results of grain yield were reported also from other researchers. Talebi et al. (2013) reported different results for grain yield which ranged from 14.75 to 23.75 with a mean value of $17.9 \mathrm{~g} \mathrm{plant}^{-1}$. Caliskan et al. (2013) also reported different results for grain yield with an average value of $23.79 \mathrm{~g} \mathrm{plant}{ }^{-1}$. 100-seed weight $(\mathrm{g})$ results ranged from 18.02 to $24.87 \mathrm{~g}$ with a mean value of 21.13 g. The physiological efficiency of chickpea plants to convert the total dry matter to grain yield can be estimated by calculating the harvest index (HI). The value of $\mathrm{HI}$ varied from $20.21 \%$ (FBV-XE) to $38.04 \%$ (FBV-TE), with significant differences among genotypes. HI obtained by Caliskan et al. (2013) varied from $21.1 \%$ to $35.1 \%$. Substantial agronomic genetic diversity is given in Table 4.

Proximate compositions of the different chickpea genotypes are shown in Table 5. Significant differences were observed among the genotypes. As shown in Table 5 , carbohydrates represent the main fraction of chickpea seed composition $(43.65-46.32 \mathrm{~g} / 100 \mathrm{~g})$. In the present study, the mean total carbohydrate value of seven chickpea genotypes was $44.64 \% \pm 0.36 \%$, lower than $67.8 \%$ total carbohydrates obtained by Shad et al. (2009). Protein mean value was $28.85 \mathrm{~g} / 100 \mathrm{~g}$. Genotypes FBVRA and FBV-FE exhibited the highest protein content (mean $=29.70 \mathrm{~g} / 100 \mathrm{~g}$ and $29.66 \mathrm{~g} / 100 \mathrm{~g}$, respectively). 
Similarly, El-Adawy (2002) reported differences among genotypes in protein content $(23.64 \mathrm{~g} / 100 \mathrm{~g}$ for Egyptian genotypes and $18.5 \mathrm{~g} / 100 \mathrm{~g}$ for Brazilian genotypes). Oil content mean value of the evaluated genotypes was $2.88 \pm$ $0.02 \mathrm{~g} / 100 \mathrm{~g}$. It ranged from 2.75 to $2.95 \mathrm{~g} / 100 \mathrm{~g}$. There were significant differences among the chickpea genotypes for both the protein and oil content. Different results were reported by De Almeida Costa et al. (2006) who at some different chickpea genotypes obtained seed oil content up to $9.01 \mathrm{~g} / 100 \mathrm{~g}$. The cellulose content ranged from $8.51 \mathrm{~g} / 100 \mathrm{~g}$ to $8.86 \mathrm{~g} / 100 \mathrm{~g}$ in genotypes, showing significant differences between them. FBV-RA had the highest cellulose content $($ mean $=8.86 \mathrm{~g} / 100 \mathrm{~g}$ ) and FBV-SU contained the lowest value (mean $=8.51$ $\mathrm{g} / 100 \mathrm{~g})$.

Table 3. Mean square of some traits in chickpea genotypes

\begin{tabular}{|c|c|c|c|c|c|c|c|c|c|}
\hline $\begin{array}{l}\text { Sources of } \\
\text { variation }\end{array}$ & $\begin{array}{l}\text { Biological } \\
\text { yield }\end{array}$ & $\begin{array}{l}\text { Shoot } \\
\text { biomass }\end{array}$ & $\begin{array}{l}\text { Grain } \\
\text { yield }\end{array}$ & $\begin{array}{l}100 \text { seed } \\
\text { weight }\end{array}$ & $\begin{array}{l}\text { Protein } \\
\text { content }\end{array}$ & $\begin{array}{l}\text { Oil } \\
\text { content }\end{array}$ & $\begin{array}{l}\text { Cellulose } \\
\text { content }\end{array}$ & $\begin{array}{l}\text { Carbohydrate } \\
\text { content }\end{array}$ & $\begin{array}{l}\text { Harvest } \\
\text { index }\end{array}$ \\
\hline Genotypes (G) & $5.03 * *$ & $5.024 * *$ & $4.23 * *$ & $8.36 * *$ & $21.15 * *$ & $7.05 * *$ & $5.90 * *$ & $143.20 * *$ & $13.7 * *$ \\
\hline Year $(\mathrm{Y})$ & $1.81^{\mathrm{N} . \mathrm{S}}$ & $9.397 * *$ & $3.05 * *$ & $18.41^{* *}$ & $22.98 * *$ & $14.75^{* * *}$ & $19.84 * *$ & $266.4 * *$ & $10.78^{* *}$ \\
\hline $\mathrm{G} \times \mathrm{Y}$ & $0.01^{\mathrm{N} . \mathrm{S}}$ & $0.20^{\mathrm{N} . \mathrm{S}}$ & $0.96^{\mathrm{N} . S}$ & $3.54 * *$ & $0.59^{\text {N.S }}$ & $1.46^{*}$ & $4.12^{* *}$ & $0.90^{\text {N.S }}$ & $3.88 * *$ \\
\hline Error & 13.21 & 1.09 & 2.08 & 12.54 & 7.06 & 1.21 & 0.007 & 0.005 & 0.07 \\
\hline Total & 39009.7 & 41962.8 & 1303.16 & 1299.03 & 50.06 & 0.378 & 0.7432 & 36.28 & 1404.60 \\
\hline
\end{tabular}

** is significant at $p=0.05$ and $p=0.01$ respectively.

Table 4. Agronomic traits of chickpea genotypes

\begin{tabular}{llllll}
\hline Genotypes & $\begin{array}{l}\text { Biological yield } \\
\left(\text { g plant }^{-1}\right)\end{array}$ & $\begin{array}{l}\text { Shoot biomass } \\
\left(\text { g plant }^{-1}\right)\end{array}$ & $\begin{array}{l}\text { Grain yield } \\
\left(\text { g plant }^{-1}\right)\end{array}$ & $\mathbf{1 0 0 ~ s e e d ~ w e i g h t ~}(\mathbf{g})$ & Harvest Index $(\%)$ \\
\hline FBV-XE & $118.50^{\mathrm{a}}$ & $94.75^{\mathrm{a}}$ & $23.75^{\mathrm{ab}}$ & $23.94^{\mathrm{ab}}$ & $20.21^{\mathrm{g}}$ \\
FBV-SU & $67.15^{\mathrm{b}}$ & $45.83^{\mathrm{ab}}$ & $21.46^{\mathrm{ab}}$ & $18.92^{\mathrm{bc}}$ & $31.95^{\mathrm{d}}$ \\
FBV-PZ & $79.28^{\mathrm{b}}$ & $58.44^{\mathrm{ab}}$ & $20.84^{\mathrm{b}}$ & $18.02^{\mathrm{c}}$ & $26.28^{\mathrm{f}}$ \\
FBV-SU-2 & $57.65^{\mathrm{b}}$ & $39.08^{\mathrm{b}}$ & $18.57^{\mathrm{b}}$ & $18.95^{\mathrm{bc}}$ & $32.21^{\mathrm{c}}$ \\
FBV-FE & $80.36^{\mathrm{ab}}$ & $50.10^{\mathrm{ab}}$ & $30.35^{\mathrm{a}}$ & $23.49^{\mathrm{abc}}$ & $37.76^{\mathrm{b}}$ \\
FBV-RA & $67.30^{\mathrm{b}}$ & $46.23^{\mathrm{ab}}$ & $21.07^{\mathrm{ab}}$ & $24.87^{\mathrm{a}}$ & $31.30^{\mathrm{e}}$ \\
FBV-MA & $60.48^{\mathrm{b}}$ & $37.47^{\mathrm{b}}$ & $23.01^{\mathrm{ab}}$ & $19.71^{\mathrm{abc}}$ & $38.04^{\mathrm{a}}$ \\
\hline Mean & 75.82 & 53.13 & 22.72 & 21.13 & 31.10 \\
CV $(\%)$ & 27.33 & 36.96 & 16.51 & 13.49 & 3.09 \\
\hline
\end{tabular}

Values within individual columns indicated by at least one equal letter are not significantly different at 0.05 probability level.

Table 5. Proximate $(\mathrm{g} / 100 \mathrm{~g})$ and mineral $(\mathrm{mg} / \mathrm{kg})$ seed composition in chickpea genotypes

\begin{tabular}{|c|c|c|c|c|c|c|c|c|c|c|c|c|}
\hline \multirow{2}{*}{ Genotypes } & \multirow{2}{*}{$\begin{array}{l}\text { Protein } \\
\text { content }\end{array}$} & \multirow{2}{*}{$\begin{array}{l}\text { Oil } \\
\text { content }\end{array}$} & \multirow{2}{*}{$\begin{array}{l}\text { Cellulose } \\
\text { content }\end{array}$} & \multirow{2}{*}{$\begin{array}{l}\text { Carbohydrate } \\
\text { content }\end{array}$} & \multicolumn{5}{|c|}{ Micronutrients } & \multicolumn{3}{|c|}{ Macronutrients } \\
\hline & & & & & $\mathbf{Z n}$ & $\mathbf{F e}$ & $\mathrm{Cu}$ & Mn & $\mathbf{N a}$ & Mg & $\mathrm{Ca}$ & $\mathbf{K}$ \\
\hline FBV-XE & $28.87^{\mathrm{c}}$ & $2.91^{\mathrm{ab}}$ & $8.61^{\mathrm{cd}}$ & $44.51^{\mathrm{d}}$ & $24.06^{\mathrm{f}}$ & $21.42^{\mathrm{e}}$ & $2.7^{\mathrm{d}}$ & $5.68^{f}$ & $21.68^{\mathrm{f}}$ & $556.5^{\mathrm{f}}$ & $376.89^{c}$ & $5232.43^{\mathrm{d}}$ \\
\hline FBV-SU & $27.46^{\mathrm{c}}$ & $2.95^{\mathrm{a}}$ & $8.51^{\mathrm{d}}$ & $46.32^{\mathrm{a}}$ & $27.03^{\mathrm{d}}$ & $26.3^{\mathrm{d}}$ & $1.91^{\mathrm{f}}$ & $9.35^{\mathrm{d}}$ & $42.03^{c}$ & $570.23^{\mathrm{e}}$ & $403.93^{b}$ & $5472.66^{\mathrm{b}}$ \\
\hline FBV-PZ & $27.87^{\mathrm{c}}$ & $2.84^{\mathrm{b}}$ & $8.66^{\mathrm{bc}}$ & $45.39^{\mathrm{b}}$ & $24.86^{\mathrm{e}}$ & $26.19^{d}$ & $2.04^{\mathrm{e}}$ & $9.55^{\mathrm{d}}$ & $37.16^{\mathrm{e}}$ & $557.6^{\mathrm{f}}$ & $441.5^{\mathrm{a}}$ & $5378.37^{\mathrm{c}}$ \\
\hline FBV-SU-2 & $29.56^{\mathrm{ab}}$ & $2.75^{\mathrm{c}}$ & $8.86^{\mathrm{a}}$ & $43.94^{\mathrm{e}}$ & $42.91^{\mathrm{b}}$ & $32.34^{\mathrm{a}}$ & $2.69^{d}$ & $15.4^{\mathrm{a}}$ & $48.6^{\mathrm{a}}$ & $696.26^{\mathrm{a}}$ & $336.7^{\mathrm{d}}$ & $5877.63^{\mathrm{a}}$ \\
\hline FBV-FE & $29.66^{\mathrm{b}}$ & $2.96^{\mathrm{a}}$ & $8.81^{\mathrm{ab}}$ & $43.65^{\mathrm{g}}$ & $43.58^{\mathrm{a}}$ & $31.29^{\mathrm{b}}$ & $3.52^{\mathrm{b}}$ & $13.53^{\mathrm{c}}$ & 38.56 & $654.64^{\mathrm{d}}$ & $303.76^{\mathrm{e}}$ & $5930.47^{\mathrm{a}}$ \\
\hline FBV-RA & $29.70^{\mathrm{a}}$ & $2.83^{\mathrm{b}}$ & $8.86^{\mathrm{a}}$ & $43.83^{f}$ & $42.26^{\mathrm{c}}$ & $31.13^{\mathrm{b}}$ & $3.2^{\mathrm{c}}$ & $14.6^{\mathrm{b}}$ & $43.6^{\mathrm{b}}$ & $667.49^{\mathrm{b}}$ & $286.83^{f}$ & $5862.33^{\mathrm{a}}$ \\
\hline FBV-MA & $28.8^{\mathrm{b}}$ & $2.83^{\mathrm{b}}$ & $8.61^{\mathrm{cd}}$ & $44.85^{\mathrm{c}}$ & $44.09^{\mathrm{a}}$ & $30.2^{\mathrm{c}}$ & $3.64^{\mathrm{a}}$ & $14.57^{\mathrm{b}}$ & $42.65^{\mathrm{bc}}$ & $657.3^{c}$ & $280.56^{\mathrm{f}}$ & $5918.3^{\mathrm{a}}$ \\
\hline Mean & 28.85 & 2.88 & 8.7 & 44.64 & 35.54 & 28.41 & 2.81 & 11.81 & 39.18 & 622.86 & 347.17 & 5667.46 \\
\hline $\mathrm{CV}(\%)$ & 3.09 & 2.65 & 1.61 & 2.16 & 27.07 & 13.83 & 24.16 & 30.91 & 21.83 & 9.50 & 17.86 & 16.89 \\
\hline
\end{tabular}

*Values within individual columns indicated by at least one equal letter are not significantly different at 0.05 probability level.

Minerals are of great importance in the diet and need to be taken up by food, although they comprise only 4-6\% of human bodyweight. Some macro elements are required in amounts greater than $100 \mathrm{mg}$ per day but represent $1 \%$ or less of body weight (Insel et al. 2011). More than one third of the world's population is affected by iron $(\mathrm{Fe})$ and zinc $(\mathrm{Zn})$ deficiencies, which are ranked fifth and sixth among the ten most important risk causes of illness and disease in low income countries (WHO 2002). Mg, P, K and $\mathrm{Ca}$ were the main mineral elements in chickpeas (Table 5), consistent with information from the USDA (2012) database. In our study, $\mathrm{Mg}$ and $\mathrm{Ca}$ mean contents were $622.86 \mathrm{mg} \mathrm{kg}^{-1}$ and $347.17 \mathrm{mg} \mathrm{kg}^{-1}$, respectively. Ca helps to ease insomnia and helps regulate the passage of nutrients through cell walls, without calcium the muscles in the body cannot contract correctly (Payne 1990). Mn content was higher in FBV-SU-2 (15.4 $\mathrm{mg} \mathrm{kg}^{-1}$ ) and FBVRA (14.6 mg kg-1) than those of the other genotypes. Fe and $\mathrm{Zn}$ are essential micronutrients for humans. The obtained results of $\mathrm{Fe}$ and $\mathrm{Zn}$ showed higher variation between studied of chickpea genotypes. Overall average value for Fe and $\mathrm{Zn}$ was $28.41 \mathrm{mg} \mathrm{kg}^{-1}$ and $35.54 \mathrm{mg} \mathrm{kg}^{-1}$, respectively. Neugschwandtner et al. (2015) reported higher concentrations for some elements, i.e. $\mathrm{K}, \mathrm{Ca}, \mathrm{Mg}$, $\mathrm{Cu}, \mathrm{Mn}$, while the observed $\mathrm{Zn}$ concentration was similar. Quantities of minerals in cultivated plants are influenced by numerous complex factors including genotype, soil, environmental conditions and nutrition interactions (Simic et al. 2009). 
The results of the PCA of the proximate values measured were presented in Table 6. Principal component analysis can determine which of the characters most strongly contribute to the PCA. It was observed that the first component explained $96.3 \%$ of the variability among chickpea. The PC2, PC3 and PC4 accounted for additional $2.8 \%, 0.9 \%$ and $0.01 \%$ of the total variation, respectively. The first principal component and second component on maximum values was biological yield (5.94 and 11.86, respectively), while the seed protein was 1.41 . The second principal component (PC2) was determined by minerals $\mathrm{Zn}$ (0.43), Fe (0.52), Cu (1.81) and Mn (1.92). Results of cluster analysis including similarities are given in Figure 1. The seven chickpea genotypes were classified into four main groups. The cluster I comprised only FBV-XE, while cluster II consists of FBV-SU and FBV-RA with minimal differences between them. Cluster III includes the genotypes FBV-SU2 and FBV-TE. Moreover genotypes FBV-FE and FBV-PZ created their own groups alone (cluster IV).

Table 6. Eigenvector values for the first 4 principal components

\begin{tabular}{|c|c|c|c|c|}
\hline \multirow[b]{2}{*}{ Variables } & \multicolumn{4}{|c|}{ Principal components } \\
\hline & PC1 & PC2 & PC3 & PC4 \\
\hline Biological Yield & 5.94 & 11.86 & 11.71 & -0.60 \\
\hline Shoot Biomass & -5.91 & -12.19 & -11.71 & 0.56 \\
\hline 100 seed weight & -2.09 & -0.73 & -0.30 & 1.05 \\
\hline Seed protein content & 1.41 & 0.49 & 0.14 & 0.17 \\
\hline Seed oil content & 1.01 & 0.53 & -0.03 & 1.09 \\
\hline Seed cellulose content & 1.43 & 1.20 & 0.87 & -0.05 \\
\hline Seed carbohydrate content & 5.10 & 0.87 & 0.45 & -0.04 \\
\hline $\mathrm{Zn}$ & 0.57 & 0.43 & -0.17 & -0.09 \\
\hline $\mathrm{Fe}$ & -2.36 & 0.52 & 0.19 & 1.22 \\
\hline $\mathrm{Cu}$ & -1.68 & 1.81 & 3.01 & 0.16 \\
\hline $\mathrm{Mn}$ & 1.08 & 1.92 & 0.30 & -0.38 \\
\hline $\mathrm{Na}$ & 3.32 & -0.34 & -2.77 & 0.33 \\
\hline $\mathrm{Ca}$ & -4.45 & -0.28 & 2.06 & 0.08 \\
\hline $\mathrm{K}$ & -0.16 & 0.06 & -0.40 & 0.67 \\
\hline $\mathrm{Mg}$ & -0.05 & 0.37 & -0.28 & -0.55 \\
\hline Percentage variation & 96.3 & 2.8 & 0.9 & 0.01 \\
\hline Percentage cumulative & 96.1 & 99.1 & 100 & 100 \\
\hline
\end{tabular}

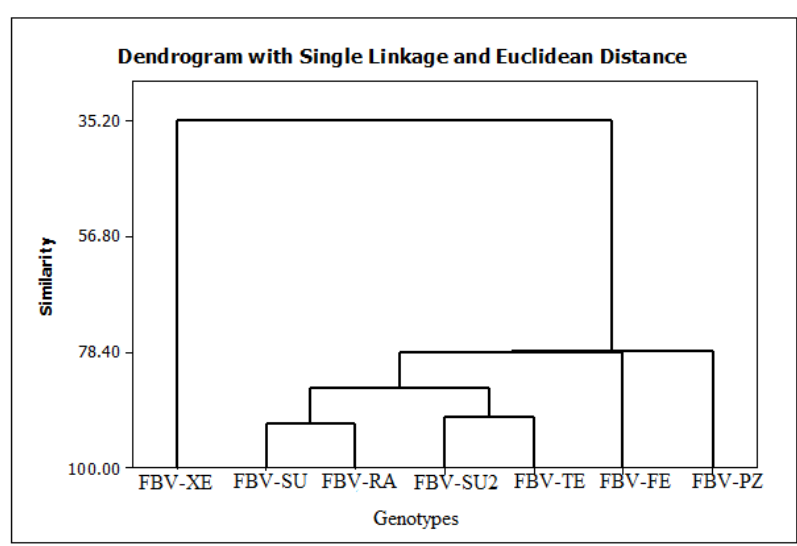

Figure 1. Results of cluster analysis including similarities for chickpea genotypes

\section{CONCLUSIONS}

The present study showed a great amount of genetic diversity among the studied genotypes and allows a better knowledge of the chickpea genotypes in different regions of Kosova. It can be concluded that the seed is a good source of protein, oil and different mineral elements. It was observed that the first two components explained more than $99 \%$ of the variability among the seven chickpea genotypes evaluated. We can also deduce that these seeds may serve as sources of minerals for human diets. Generally, results and findings from this research suggest a great chance for genetic improvements of chickpea in different breeding programs for the development of desirable genotypes through hybridization.

\section{ACKNOWLEDGMENT}

The first author would like to express their sincere appreciation to all of my coauthors for his continuous support and suggestions in editing of this article and special thanks to Prof Ludvik Rozman, University of Ljubljana, and Department of Plant Production.

\section{LITERATURE CITED}

Aliu S, Fetahu Sh. 2010. Determination on Genetic Variation for Morphological Traits and YieldComponents of New Winter Wheat (Triticum aestivum L.) Lines. Notulae Scientia Biologica 2 (1).121-124.

Aliu S, Salihu S, Rusinovci I,Fetahu Sh, Zeka D, Ibishi E. 2015. Variacioni gjenetik i qiqrës (cicer arietinum 1.) për veçori morfologike dhe vlera ushqyese. Java e shkences, Prishtine.

Anbessa Y, Warkentin T, Bueckert R, Vandenberg A, 2007. Short internode, double podding and early flowering effects on maturity and other agronomic characters in chickpea. Field Crops Research.102: 43-50. 
Caliskan, S., Erdogan, C., Arslan, M. and M.E. Caliskan. 2013. Comparison of organic and traditional production systems in chickpea (Cicer arietinium L.). Turkish Journal Field Crops 18:34-29.

Caliskan S., Erdogan C., Arslan M., Caliskan M. 2013.Comparison of organic and traditional production systems in chickpea (Cicer arietinum L.). Turkish Journal of Field Crops. 18(1), 34-39.

De Almeida Costa, G.E., Da Silva Queiroz-Monici, K., Pissini Machado Reis, S. and Costa De Oliveira, A. 2006. Chemical composition, dietary fibre and resistant starch contents of raw and cooked pea, common bean, chickpea and lentil legumes. Food Chemistry, 94, 327-330.

El-Adaway, T. 2002. Nutritional composition and nutritional factors of chickpeas (Cicer arietinum L.) undergoing different cooking methods and germination. Plant Foods for Human Nutrition, 57, 83-97.

Food and Agricultural Organization of the United Nations. 2013. FAO Statistical Databases. Available at http://faostat.fao.orgl FAO, Rome.

Gargo M. 1997.Zitarice i zrnate mahunarke. Zagreb. 238-241 pp.

Harlan J.R. 1992. Crops and Man. Foundation for Modern Crop Science. American Society of Agronomy, Madison.

Hasanuzzaman M., Karim M., Quazi A and Kamrun N. 2007. Yield Performance of Chickpea Varieties Following Application of Growth Regulator. American-Eurasian Journal of Scientific Research 2 (2): 117-120.

Hulse JH, 1991. Nature, composition and utilization of grain legumes. In: Uses of tropical Legumes: Proceedings of a Consultants' Meeting. 27-30 March 1989, ICRISAT Center ICRISAT, Patancheru, A.P. 502324 India, pp. 11-27.

HMIK. 2014. Hydro-meteorological Institute of Kosovo; Data base for sum of Temperatures and Rainfall, Prishtine.

Insel P, Ross D, Mc Mahon K, Bernstein M .2011. Nutrition, Sudbury Massachusetts, 4th edn. Jones and Bartlett Publishers, USA.

Ladizinsky and Adler 1976. Genetic relationship among the Annual species of cicer L. Theoretical and applied genetics 48,197-203.

Miller, P.R., McConkey, B.G., Clayton, G.W., Brandt, S.A., Staricka, J.A., Johnston, A.M., Lafond, G.P., Schatz, B.G., Baltensperger, D.D. and K.E. Neill. 2002. Pulse crop adaptation in the northern Great Plains. Agronomy Journal. 94:261-272.

Neugschwandtner, R., H. Wagentrist H., H.-P. Kaul. 2014. Nitrogen concentrations and nitrogen yields of above-ground dry matter of chickpea during crop growth compared to pea, barley and oat in central Europe. Turkish Journal of Field Crops 19(1), 136-141.

Neugschwandtner, R., H. Wagentrist H., H.-P. Kaul. 2015. Concentrations and uptake of macro and micronutrients by chickpea compared to pea, barley and oat in Central Europe. Journal fuer Kulturpflanzen 67(12), in press.

Neugschwandtner, R.W., S. Wichmann, D.M. Gimplinger, H. Wagentristl, H.-P. Kaul. 2013. Chickpea performance compared to pea, barley and oat in central Europe: growth analysis and yield. Turkish Journal of Field Crops 18(2), 179-184.

Payne, W. J. A. 1990. An Introduction to Animal Husbandry in the Trophics. Longman Publishers Singapore ; 92-110.

Sahin, N., and H.H. Gecit, 2006. The effects of different fertilizing methods on yield and yield components in chickpea (Cicer arietinum L.). Journal of Agricultural Scientia., 12 (3): 252-258.

SPSS-16. 2006. Statistical package programme

Šimič D., R. Sudar, T.Ledencan, A. Jamnrovic, Z. Zdunic, I. Brkic, V. Kovacevic .2009. Genetic variation of bioavailable iron and zinc in grain of a maize population. Journal of Cereal science. 50. .392-397.

Shad, M.A., Pervez, H., Zafar, Z.I., Zia-Ul-Haq, M. and Nawaz, H. 2009. Evaluation of biochemical composition and physicoquemical parameters of oil from seeds of desi chickpea varieties cultivated in arid zone of Pakistan. Pakistan Journal of Botany, 41, 655-662.

Smýkal, P., CJ Coyne, MJ Ambrose, N Maxted, H Schaefer, MW Blair, Jens Berger, Stephanie L. Greene, MatthewN. Nelson, Naghmeh Besharat, Tomáš Vymyslický, Cengiz Toker, Rachit K.Saxena, Manish Roorkiwal, Manish K. Pandey, Jinguo Hu, Ying H. Li, Li X.Wang, Yong Guo, Li J. Qiu, Robert J. Redden \& Rajeev K. Varshney ..2015. Legume crops phylogeny and genetic diversity for science and breeding. Critical Reviews in Plant Sciences 34 (1-3), 43-104.

Talebi R, Fayaz R, Mardi M, Pirsyedi SM, Naji AM. 2008. Genetic relationships among chickpea (Cicer arietinum) elite lines based on RAPD and agronomic markers. International Journal of Agricultural Biology,8:1560-8530.

Toker, C. 2004. Evaluation of yield criteria with phenotypic correlations and factor analysis in chickpea. Acta Agriculturae Scandinavica. Section B-Soil \& Plant Science 54 (1), 45-48.

Toker, C., B. Uzun, F.O. Ceylan, and C. Ikten, 2014. Chickpea. In: Alien Gene Transfer in Crop Plants, A. Pratap and J. Kumar Eds., Volume 2, Springer, Dordrecht, pp: 121-151.

Toker, C., M.I. Cagirgan, 2004. The use of phenotypic correlation and factor analysis in determining characters for grain yield in chickpea (Cicer arietinum L.). Hereditas, 140 (3): 226-228.

Tonk, F.A., E. Ilker, M. Tosun, 2010. A study to incorporate high protein content from tetraploid wheat ( $T$. turgidum dicoccoides) to hexaploid wheat (T. aestivum vulgare). Turk J Field Crops 15: 69-72.

Talebi R, Rokhzadi. A. 2013. Genetic diversity and interrelationships between agronomic traits in landrace chickpea accessions collected from 'Kurdistan' province, north-west of Iran. International Journal of Agriculture and Crop Sciences. Vol., 5 (19), 2203-2209.

United States Department of Agriculture-Agricultural Re- search Service 2012. Nutrient database for standard reference.

Updegraff, D. M. 1969. Semimicro determination of cellulose in biological materials. Analytical Biochemistry, 32, 420-424.

van Der Maesen LJG. 1987. Origin, history and taxonomy of chickpea. In: Saxena MC, Singh K (eds.): The Chickpea. CAB Inter, Wallingford: 11-34.

Zia-Ul-Haq, M., M. Ahmad, S. Iqbal, S. Ahmad and A. Hakoomat, 2007. Characterization and compositional study of oil from seeds of desi chickpea (Cicer areitinum L.) cultivars grown in Pakistan. Journal of American Oil Chem. Society., 84: 1143-1148.

Zohary D., Hopf M. 2000. Domestication of Plants in the Old World. 3rd Ed. Oxford University Press, Oxford. World Health Organization (WHO). 2002. The world health report, Geneva 